\title{
The European University President: An Unknown Species
}

\author{
Ulrich Teichler \\ Ulrich Teichler is professor at the Center for Research on Higher \\ Education and Work, University of Kassel, Germany. E-mail: \\ <cassidy@ Hochschulforschung.uni-kassel.de>.
}

$\mathrm{E}$ xperts agree that the role of the university president (rector, vice-chancellor, or similar title) in most European countries increased in importance and power in the 1980s and 1990s. Contributing to the growing reliance on the university president as the savior of higher education were the dissatisfaction with the effectiveness of government steering; calls for social utility and relevance in higher education; pressures for diversification and specialized profiling of institutions and programs; the need for greater efficiency amid stagnating resources and growing student numbers and research costs; loss of confidence in self-regulation of the academic profession; and increasing confidence in the potential of institutional management and leadership.

The interest Europeans have shown in reasonable revisions of the president's role is based not only on experiences in their home environment but also on reports of approaches tried in other countries. Notably, the "American romance with leadership" has sparked debates about the changing role of the university president in Europe.

A note of caution is appropriate when generalizing about the European scene. Whereas in the 1980s and 1990s, the governments of countries on the continent reduced their traditionally strong supervisory mechanisms over higher education, the British government no longer accepted the traditional autonomy of the universities. There are also major differences between countries influenced by the Humboldtian model and those influenced by the Napoleonic model as well as between individual countries.

The vast literature on changes in university governance examines the forces, expectations, and constraints affecting the university and the impressive room for manoeuvre by the individual university president. However, few publications look systematically at the way presidents think and act. Research is also scarce concerning faculty and student views on administration in higher education and the role played by university presidents.

\section{Selective Overview of Research}

Views of academics were analysed in a 1992 international survey that was coordinated by the Carnegie Foundation for the Advancement of Teaching. When asked whether they agreed or disagreed that "top-level administrators are providing competent leadership," university professors in Germany, the Netherlands, Sweden, and the United
Kingdom responded ambivalently-neither positively nor negatively. Junior academic staff at universities and academics at other higher education institutions had an even more negative opinion of institutional leaders.

U.S. academics at research universities do not rate their institutional leaders as more competent than do their European colleagues. However, U.S. academics at other colleges are less critical of their leaders less negatively than their European colleagues. Japanese university professors rate the competence of their university leaders most positively among the academics surveyed. A closer look, however, reveals that most Japanese academics consider the university leadership to be much weaker than do their colleagues in Europe and the United States. Japanese university leaders are not viewed as powerful and competent leaders but rather as administrators competently performing their tasks.

In a 1995 survey conducted by the Center for Higher Education Policy Studies (CHEPS) of Twente University, in the Netherlands, rectors from Germany, Denmark, France, the Netherlands, Sweden, and the United Kingdom were asked to determine the role various actors play in governance and decision making. The rectors surveyed do not consider the central administrators (i.e., themselves and other persons in leading positions) to be the dominant decision makers at institutions of higher education. Rather, they see themselves as actively involved in decision making along with other actors-such as, academics, central councils, and other administrators and councils.

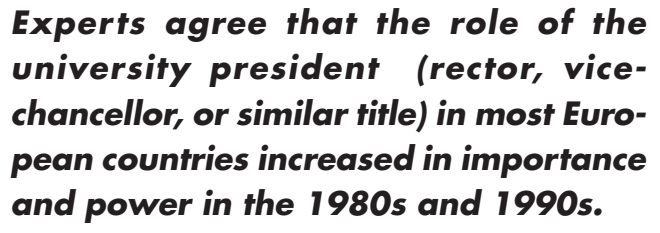

In the CHEPS study, the rectors indicate that they are most involved in decisions on matters of the budget and the selection of administrative staff. They also see themselves as participating actively in decisions regarding institutional policy, considerably less involved in teaching and the selection of professors, and least concerned with research.

A 1994 survey conducted by researchers at the Center for Research on Higher Education and Work, at the University of Kassel, Germany is focused on the role key managers (rectors, etc.) play in the development of European Union activities. The questionnaire was 
mailed to rectors but was often responded to by heads of the international offices.

In most of the countries, the international officers alone or together with academics or other administrators were viewed as the key forces. However, in Belgium, Germany, and the United Kingdom, academics were viewed as central. These findings suggest that the active participation of rectors in developing European mobility and cooperation was not an expression of managerial and strategic strength. On the contrary, the rectors seemed to have played a strong role in this area, even in countries where they had limited managerial and strategic functions.

The final example in this overview is the 1993 pilot study on the strategies and self-perception of university presidents undertaken by the Center in Kassel showing that university presidents consider having to balance their various roles the most challenging and difficult task. Presidents have to manage the formal apparatus of administration, represent divergent interest groups, be aware of major developments in teaching and research, and serve as spokespersons for the mission and dignity of the institutions. The interviewed presidents underscored that they constantly felt the need to transform formal mechanisms and procedures into informal processes of communication and negotiation.

\section{Ideas for Future Research}

A comparative survey of how university presidents perceive themselves would be a most fascinating higher education research project. Major changes in higher education have called for changes in the role of the key players in higher education institutions, but it is not known how these individuals perceive and cope with such changes. Such a study would need to explore how presidents perceive the current conditions in higher education; how they react to the new expectations; what actions they have taken; and finally, how they judge the impact of their actions.

A broad range of issues that influence patterns of decision making and administration should be explored (e.g., national cultures, the organizational character of higher education institutions, and national regulatory systems). Attention should be paid to the composition and authority of the major actors involved in higher education. The role of the president also needs to be examined.

Research on the university president ought to address personal biography and include prior professional experience, academic expertise, age and gender, political views, and other factors. These issues and factors may influence the way university presidents respond to the challenges they face and the way they decide to act.

\section{Conclusion}

Reforms of the structure and organization of higher education tend to be pursued episodically. Typically, problems are identified, measures are taken, and hopes for success run high. After a period of time, attention to the issues levels off, partly because of certain successfully implemented changes, partly because the anticipated miraculous impacts did not materialize, and partly because other issues became more relevant.

If it is true that a spirit of managerialism was a fad bound to lose momentum without a return to the status quo ante, then a study on the university president might be forwardlooking by already focusing on the character of the "postmanagerial" interpretation of the president's role. One might try to establish how the views of the president differ depending on the stage of managerial debates within a given country, the period of time the individual had already been in office, and the person's ability to understand and fulfill complex roles. With this more comprehensive approach, a study on the university president might be more than just a snapshot.

Author's Note: This text was presented at the 12th triennial conference of the International Association of University Presidents (IAUP), 11-14 July 1999, in Brussels.

\section{The Crisis in Multinational Higher Education}

\section{Philip G. Altbach}

Philip G. Altbach is J. Donald Monan SJ professor of higher education and director of the Center for International Higher Education at Boston College.

M ultinational higher education is big business, and it is about to get much bigger. Glenn R. Jones recently became the chairman and CEO of GATE, the Global Alliance for Transnational Education, an organization that has the aim of fostering and maintaining quality in cross-border higher education enterprises. This is notable because Jones is also responsible for Jones International University, a forprofit provider of on-line educational programs. GATE moved from its location at the Dupont Circle complex of higher education associations in Washington, D.C., to Englewood, Colorado, the headquarters of the Jones educational enterprises. GATE, which was largely funded by Jones, is now directly linked with a profit-making corporation in the international education business, and is unlikely to be considered 